\title{
Kibdelosporangium albatum sp. nov., Producer of the Antiviral Antibiotics Cycloviracins

\author{
KOJI TOMITA, ${ }^{*}$ YUTAKA HOSHINO, AND TAKEO MIYAKI \\ Bristol-Myers Squibb Research Institute, 2-9-3 Shimo-meguro, Meguro-ku, Tokyo 153, Japan
}

\begin{abstract}
A new species of the genus Kibdelosporangium is described. This soil organism forms long straight spore chains and numerous sporangiumlike structures on the aerial mycelium. The new species has type IV cell walls and pattern A whole-cell sugars (meso-diaminopimelic acid, arabinose, and galactose are present), type PII phospholipids, MK-9 $\left(\mathrm{H}_{4}\right)$ as the major menaquinone, and no mycolic acids. On the basis of morphology and chemotaxonomy, the single isolate is assigned to the genus Kibdelosporangium. The isolate differs from two previously described species of the genus in fatty acid composition, the absence of melanin formation, and many physiological and biochemical characteristics and is identified as a new species. Accordingly, the name Kibdelosporangium albatum sp. nov. is proposed for this isolate. The type strain is R761-7 (= ATCC 55061).
\end{abstract}

In the course of isolating uncommon actinomycetes for our antibiotic screening program, strain $\mathrm{R} 761-7^{\mathrm{T}}(\mathrm{T}=$ type strain) was isolated from a tropical soil sample. This strain produces a complex of new acyl saccharide antibiotics, cycloviracins active against herpes simplex virus $(16,17)$.

The genera of actinomycetes with type IV cell walls are divided into taxa (possibly two families) on the basis of presence or absence of mycolic acids (6). The mycolatecontaining taxon is comprised of the genus Nocardia and related genera. The mycolateless wall IV actinomycetes are a recently expanded taxon because of the reclassification or the discovery of new genera, including the genera Actinopolyspora, Amycolata, Amycolatopsis, Faenia, Pseudonocardia, Saccharomonospora, and Saccharopolyspora (6). The genus Pseudoamycolata was recently added to this taxon (1). The eight genera are distinguished from each other on the basis of morphology, chemotaxonomy, and a few physiological characteristics $(1,7)$, but form a distinct group on the basis of the results of an analysis of 16S rRNA sequences from representative strains $(3,5)$. For this group, a new family name, Pseudonocardiaceae, was proposed (3, 5).

The genus Kibdelosporangium, described by Shearer et al. (13), also belongs to the mycolateless wall IV actinomycete group. Kibdelosporangia are characterized by the abundant formation of pseudosporangia with enveloping hyphae that contain no spores, together with long chains of aerial spores. In this paper we describe strain $R 761-7^{\mathrm{T}}$ and, on the basis of its distinctive characteristics, propose the name Kibdelosporangium albatum sp. nov. for this organism.

\section{MATERIALS AND METHODS}

Strain R761- $7^{\mathrm{T}}$ was isolated from a soil sample collected on Mindanao Island, Philippines. The isolation procedure used for the strain was as follows. The pulverized dry soil sample was transferred with a nylon sponge to an agar medium, which contained (per $1,000 \mathrm{ml}$ of distilled water) 5.0 $\mathrm{g}$ of soluble starch, $5.0 \mathrm{~g}$ of glucose, 1.0 of yeast extract, 2.0 $\mathrm{g}$ of NZ-case, $1.0 \mathrm{~g}$ of $\mathrm{CaCO}_{3}, 20 \mathrm{ml}$ of $\mathrm{V}-8$ juice (Campbell Japan Corp.), and $16 \mathrm{~g}$ of agar ( $\mathrm{pH}$ 7.2). The agar medium

\footnotetext{
* Corresponding author.
}

was supplemented with $4 \mu \mathrm{g}$ of ampicillin per $\mathrm{ml}, 10 \mu \mathrm{g}$ of nalidixic acid per $\mathrm{ml}$, and $80 \mu \mathrm{g}$ of nystatin per $\mathrm{ml}$. The agar plate was incubated at $43^{\circ} \mathrm{C}$. This strain has been deposited with the American Type Culture Collection, Rockville, Md., under accession number ATCC 55061. Kibdelosporangium aridum Shearer, Colman, Ferrin, Nisbet, and Nash strain ATCC $39323^{\mathrm{T}}$ (13) was used for a comparative study, and data for Kibdelosporangium philippinense Mertz and Yao were obtained from the literature (10).

The cultural and physiological characteristics of the strain were examined by the methods of Shirling and Gottlieb (15) and Shearer et al. (13). The diaminopimelic acid isomer and sugar in the whole-cell hydrolysate and the amino acids in purified cell walls were analyzed by the methods of Lechevalier (8) and Becker et al. (2), respectively. The phospholipids were identified by the procedure of Lechevalier et al. (9). The menaquinone samples were prepared by the procedure of Collins et al. (4) and were analyzed by mass spectroscopy (model JMS-AX505H; JEOL Corp., Tokyo, Japan). The detection of mycolates and the glycolate test were carried out by the methods of Minnikin et al. (11) and Uchida and Aida (18), respectively. The composition of methyl-esterified

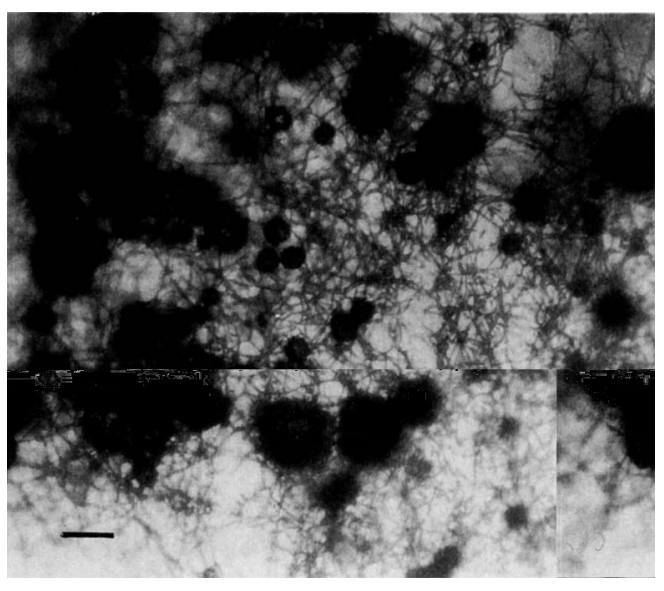

FIG. 1. Photograph of abundant sporangiumlike bodies beneath the aerial hyphae (culture grown on ISP medium 2 at $28^{\circ} \mathrm{C}$ for 3 weeks). Bar $=20.0 \mu \mathrm{m}$. 


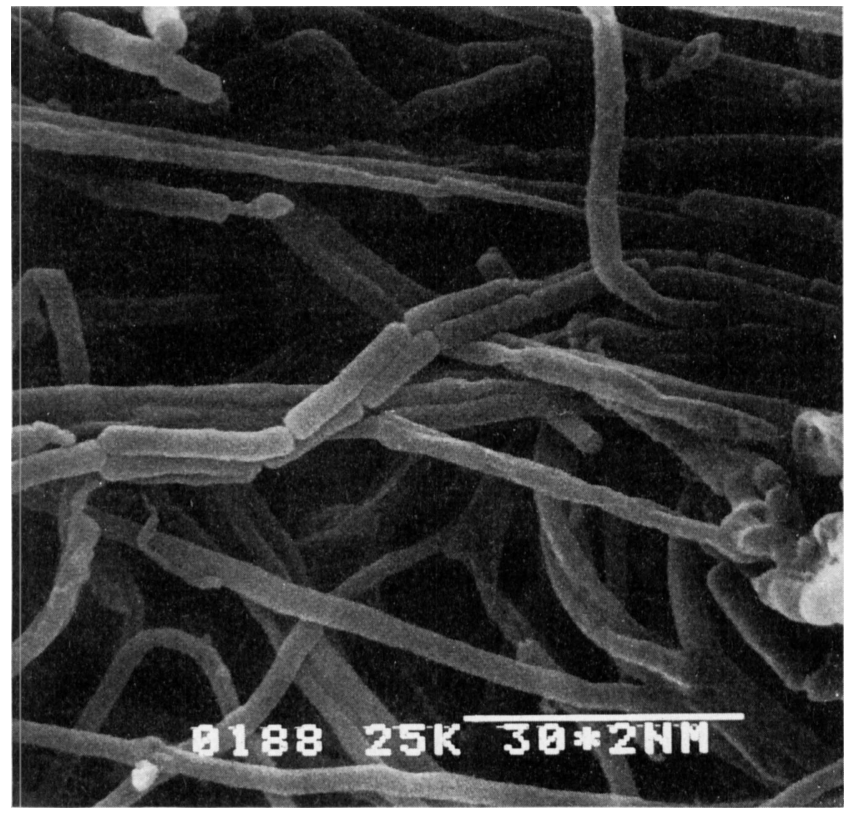

FIG. 2. Scanning electron micrograph of spore chains (culture grown on ISP medium 4 at $28^{\circ} \mathrm{C}$ for 3 weeks). Bar $=3.0 \mu \mathrm{m}$.

cellular fatty acids was analyzed by gas chromatography with an SPB-1 fused-silica capillary column $(0.25 \mathrm{~mm}$ by 30 m) and by gas chromatography (model 5890 ; Hewlett-Packard, Pittsburgh, $\mathrm{Pa}$.)-mass spectrometry.

\section{RESULTS}

Morphology. Strain R $761-7^{\mathrm{T}}$ is a gram-positive, non-acidfast organism that forms well-branched substrate and aerial mycelia. The substrate mycelium exhibited various degrees of fragmentation and bore a specialized structure which appeared to be dichotomously branched and contained fused hyphae. The aerial mycelium formed long, straight chains of spores and numerous sporangiumlike globular bodies, 8 to 20 $\mu \mathrm{m}$ in diameter. The spores were cylindrical $(0.4$ by 0.8 to $2.0 \mu \mathrm{m})$ and had smooth surfaces without a distinct sheath (Fig. 1 through 3). Globular bodies were observed initially as a droplet (balloonlike) at the tip of a stalk, which eventually became a sporangiumlike body. The mature sporangiumlike bodies were surrounded by a membranous envelope and contained irregularly curved hyphae but no spores. Cells of all structures were nonmotile.

Cultural characteristics. The degrees of growth and colors of the aerial and substrate mycelia of strain $R 761-7^{\mathrm{T}}$ on various media are shown in Table 1. White or yellow aerial mycelia were formed on most agar media. The substrate mycelium was colorless to orange-yellow or yellowish brown. Melanin and other distinct pigments were not produced.

Physiological and biochemical characteristics. Physiological and biochemical characteristics of strain $\mathrm{R} 761-7^{\mathrm{T}}$ are presented in Table 2. Growth of R761-7 ${ }^{\mathrm{T}}$ occurred between 17 and $45^{\circ} \mathrm{C}$. Optimal growth was at $37^{\circ} \mathrm{C}$. No growth was observed at 14 or $48^{\circ} \mathrm{C}$. The strain tolerated up to $4 \%$ $\mathrm{NaCl}$.

Chemotaxonomy. Whole-cell hydrolysates contained meso-diaminopimelic acid, rhamnose, arabinose, glucose,

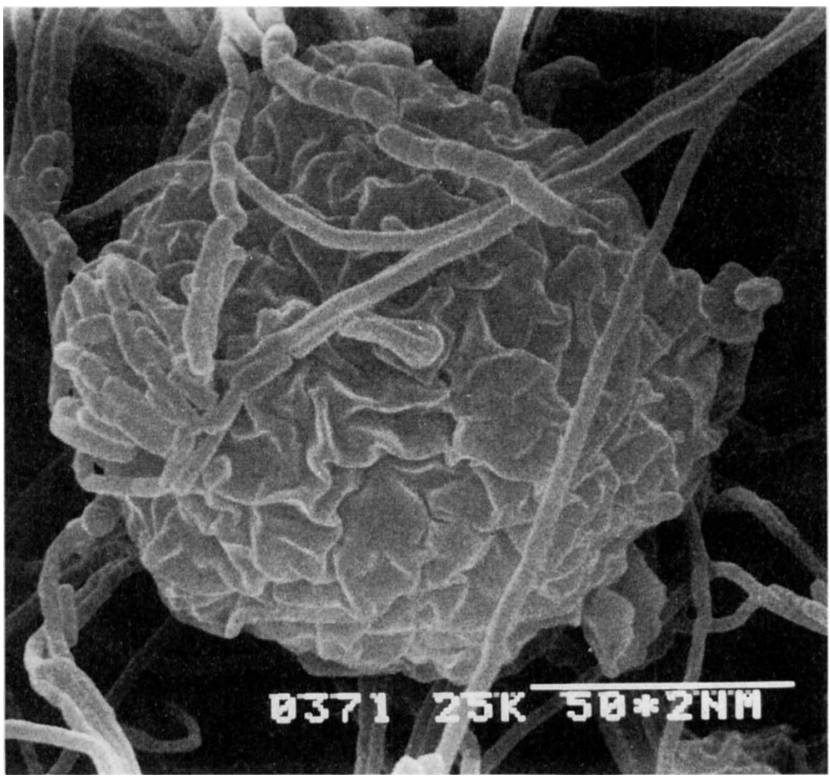

FIG. 3. Scanning electron micrograph of a sporangiumlike body beneath the covering of spore chains (culture grown on ISP medium 3 at $28^{\circ} \mathrm{C}$ for 3 weeks). Bar $=5.0 \mu \mathrm{m}$.

and galactose. Madurose was not detected. The purified cell wall contained meso-diaminopimelic acid, glutamic acid, and alanine. The phospholipids contained phosphatidylethanolamine, phosphatidylmethylethanolamine, phosphatidylglycerol, and phosphatidylinositol. Therefore, strain R761-7 had type IV cell walls with sugar pattern A and type PII phospholipids. The major menaquinone was MK-9 $\left(\mathrm{H}_{4}\right)$. The menaquinone composition of strain R761- $7^{\mathrm{T}}$ was as follows: MK-9 $\left(\mathrm{H}_{0}\right), 6 \%$; MK-9 $\left(\mathrm{H}_{2}\right)$, 13\%; MK-9( $\left.\mathrm{H}_{4}\right), 67 \%$; MK$9\left(\mathrm{H}_{6}\right), 10 \%$, and MK- $9\left(\mathrm{H}_{8}\right) 4 \%$. Mycolates were absent. The glycolate test was negative; hence, the $N$-acyl type of peptidoglycan was acetyl. The major fatty acids were hexadecanoic acid $(10 \%)$, heptadecanoic acid (13\%), 15-methylpentadecanoic acid (38\%), and 14-methylhexadecanoic acid $(10 \%)$, there were also minor amounts of unsaturated fatty acids, but 10-methyl or 2-hydroxy fatty acids were not detected. The fatty acid composition of strain $R 761-7^{\mathrm{T}}$ was as follows: straight-chain 15:0 acid (pentadecanoic acid), 5\%; straight-chain 16:0 acid, 10\%; straight-chain 17:0 acid, $13 \%$; straight-chain 18:0 acid, $4 \%$; branched-chain i-14 acid, $3 \%$; branched-chain i-15 acid, $8 \%$; branched-chain i-16 acid (15-methylpentadecanoic acid), 38\%; branched-chain i-17 acid, 3\%; branched-chain i-18 acid, $1 \%$; branched-chain a-15 acid, $2 \%$; branched-chain a-17 acid (14-methylhexadecanoic acid), 10\%; unsaturated cis-9 15:1 acid, $2 \%$; and unsaturated $\mathrm{i}-16: 1,1 \%$.

\section{DISCUSSION}

Identity of genus and species. Strain R761- $7^{\mathrm{T}}$ forms aerial sporangiumlike bodies containing hyphae but not spores, along with long aerial spore chains, and has the following cellular composition: type IV wall, pattern A whole-cell sugars, type PII phospholipids, MK-9 $\left(\mathrm{H}_{4}\right)$ menaquinone, iso- and anteiso fatty acids as the major fatty acid components, and no mycolates. On the basis of these morphological and chemical characteristics, strain $R 761-7^{\mathrm{T}}$ is identified as a member of the genus Kibdelosporangium. This genus 
TABLE 1. Cultural characteristics of strain R761- ${ }^{\mathrm{Ta} a}$

\begin{tabular}{|c|c|c|c|c|}
\hline Medium & Growth & Aerial mycelium & Substrate mycelium & Diffusible pigment \\
\hline $\begin{array}{l}\text { Sucrose-nitrate agar } \\
\text { (Czapek-Dox agar) }\end{array}$ & Good & Pale yellow $(89)^{b}$ & Orange-yellow (71) & Light yellowish brown (76) \\
\hline $\begin{array}{l}\text { Tryptone-yeast extract } \\
\text { broth (ISP medium 1) }\end{array}$ & $\begin{array}{l}\text { Moderate, pellicle, } \\
\text { not turbid }\end{array}$ & None & Light yellowish brown (76) & None \\
\hline $\begin{array}{l}\text { Yeast extract-malt extract } \\
\text { agar (ISP medium 2) }\end{array}$ & Good & White & Deep yellow (85) & None \\
\hline $\begin{array}{l}\text { Oatmeal agar (ISP } \\
\text { medium 3) }\end{array}$ & Moderate & White to light yellow (86) & Colorless to light brown (57) & None \\
\hline $\begin{array}{l}\text { Inorganic salts-starch agar } \\
\text { (ISP medium 4) }\end{array}$ & Good & Yellowish white (92) & Yellowish brown (77) & None \\
\hline $\begin{array}{l}\text { Glycerol-asparagine agar } \\
\text { (ISP medium 5) }\end{array}$ & Moderate & Yellowish white (92) & Brilliant orange-yellow (67) & None \\
\hline $\begin{array}{l}\text { Peptone-yeast extract-iron } \\
\text { agar (ISP medium 6) }\end{array}$ & Moderate & White & Vivid yellow (82) & Pale yellow (89) \\
\hline $\begin{array}{l}\text { Tyrosine agar (ISP } \\
\text { medium 7) }\end{array}$ & Moderate & White & Brilliant orange-yellow (67) & Light orange-yellow (70) \\
\hline Glucose-asparagine agar & Poor & White & Pale yellow (89) & None \\
\hline
\end{tabular}

${ }^{a}$ Cultures were observed after incubation at $28^{\circ} \mathrm{C}$ for 3 weeks.

b The color names and designations (in parentheses) were determined by comparison with ISCC-National Bureau of Standards (U.S. Department of Commerce, Washington, D.C.) color name charts.

includes two other species, $K$. aridum Shearer, Colman, Ferrin, Nisbet, and Nash $(13,14)$ and $K$. philippinense Mertz and Yao (10).

As shown in Table 3 , strain $\mathrm{R} 761-7^{\mathrm{T}}$ differs from the previously described Kibdelosporangium species. There- fore, this strain is proposed as a new species, Kibdelosporangium albatum.

Description of Kibdelosporangium albatum sp. nov. Kibdelosporangium albatum (al' ba. tum. L. adj. albatus, clothed in white, referring to the color of the aerial mycelium and the

TABLE 2. Physiological and biochemical characteristics of strain R761- $7^{\mathrm{T}}$

\begin{tabular}{|c|c|c|c|}
\hline Characteristic & Reaction $^{a}$ & Characteristic & Reaction \\
\hline \multicolumn{4}{|l|}{ Acid produced from: } \\
\hline 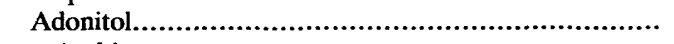 & + & 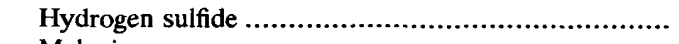 & + \\
\hline 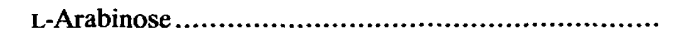 & + & 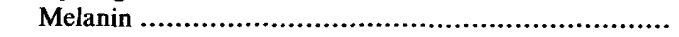 & - \\
\hline 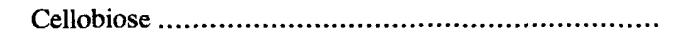 & + & Hydrolysis of: & \\
\hline 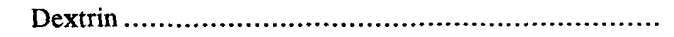 & + & Potato starch ............... & + \\
\hline 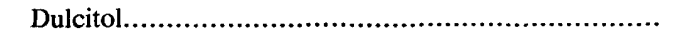 & - & 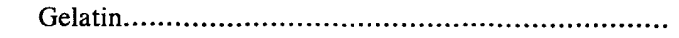 & + \\
\hline i-Erythritol .............................. & - & & \\
\hline 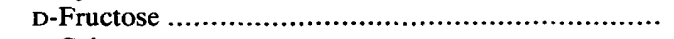 & + & Utilization of: & \\
\hline D-Galactose ......................... & + & .............................. & - \\
\hline 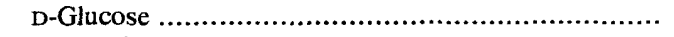 & + & 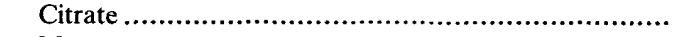 & - \\
\hline Glycerol .................................. & + & 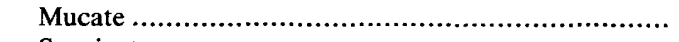 & - \\
\hline 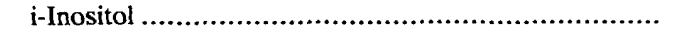 & + & 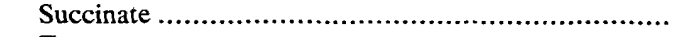 & + \\
\hline 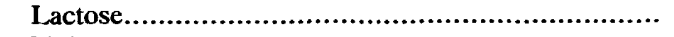 & $+(\mathbf{w})$ & 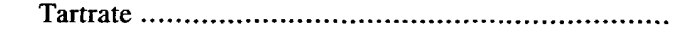 & - \\
\hline 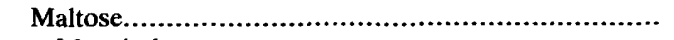 & + & & \\
\hline 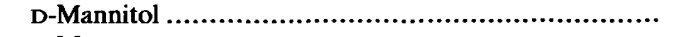 & + & Decomposition of: & \\
\hline 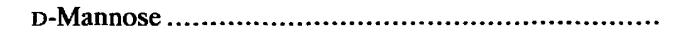 & + & 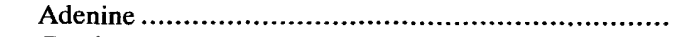 & - \\
\hline 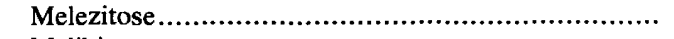 & - & 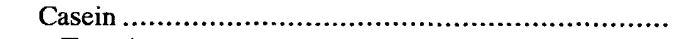 & + \\
\hline Melibiose ............................................... & - & 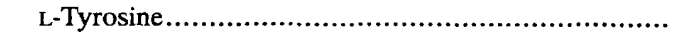 & + \\
\hline 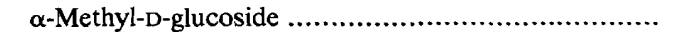 & - & 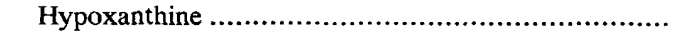 & - \\
\hline 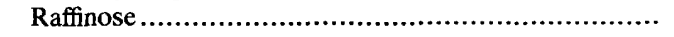 & - & 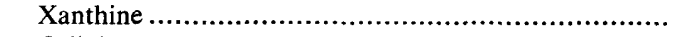 & - \\
\hline 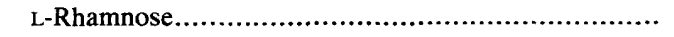 & + & 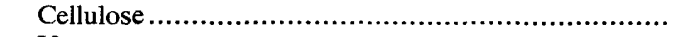 & - \\
\hline 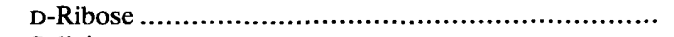 & + & 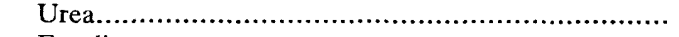 & + \\
\hline 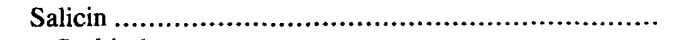 & + & Esculin ..................................................... & + \\
\hline 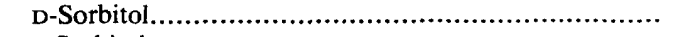 & - & 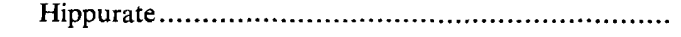 & + \\
\hline 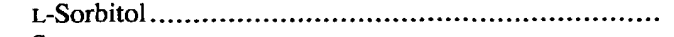 & - & & \\
\hline 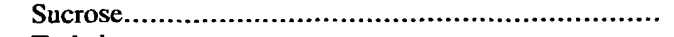 & + & & \\
\hline 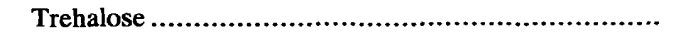 & + & Temp range for growth $\left({ }^{\circ} \mathrm{C}\right) \ldots \ldots \ldots \ldots \ldots \ldots \ldots \ldots$ & $17-45$ \\
\hline 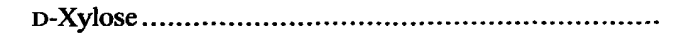 & + & Growth in the presence of: & \\
\hline Production of: & & Lyzozyme $(0.01 \%) . . . \ldots \ldots \ldots \ldots \ldots . . . . .$. & $+(w)$ \\
\hline 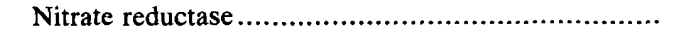 & - & 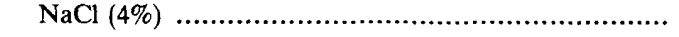 & + \\
\hline 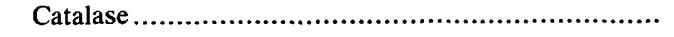 & + & & \\
\hline
\end{tabular}

$a+$, positive; -, negative; $+(w)$, weakly positive. 
TABLE 3. Characteristics differentiating the species of the genus Kibdelosporangium

\begin{tabular}{|c|c|c|c|}
\hline Characteristic & $\mathrm{R} 761-7^{\mathrm{T}}$ & $\begin{array}{l}K . \text { aridum ATCC } 39323 \\
\text { and } K \text {. aridum subsp. } \\
\text { largum ATCC } 39922^{a}\end{array}$ & $\begin{array}{l}\text { K. philippinense } \\
\text { NRRL } 18198\end{array}$ \\
\hline \multicolumn{4}{|l|}{ Acid produced from: } \\
\hline Adonitol & + & - & - \\
\hline L-Arabinose & + & + & - \\
\hline Dextrin & + & + & - \\
\hline Melezitose & - & + & + \\
\hline Melibiose & - & + & + \\
\hline$\alpha$-Methyl-D-glucoside & - & + & + \\
\hline Raffinose & - & + & - \\
\hline Salicin & + & $\mathbf{v}$ & - \\
\hline Sucrose & + & + & - \\
\hline \multicolumn{4}{|l|}{ Production of: } \\
\hline Nitrate reductase & - & - & + \\
\hline Melanin & - & + & + \\
\hline Hydrolysis of potato starch & + & - & - \\
\hline Utilization of citrate & - & + & + \\
\hline Decomposition of hypoxanthine & - & + & + \\
\hline $\mathrm{NaCl}$ tolerance $(\%)$ & 4 & $5-7$ & 2 \\
\hline Antibiotic(s) produced & $\begin{array}{l}\text { Acyl saccharide } \\
\text { (cycloviracin) }\end{array}$ & $\begin{array}{c}\text { Glycopeptides } \\
\text { (aridicin and kibdelin) }^{b}\end{array}$ & Glycopeptide $(\mathrm{A}-80407)^{c}$ \\
\hline \multicolumn{4}{|l|}{ Cell chemistry } \\
\hline $\mathrm{PME}^{d}$ & Present & Present & Absent \\
\hline Saturated straight-chain fatty acids & Major component & Minor component & Minor component \\
\hline
\end{tabular}

nonchromogenicity of the organism). Aerobic actinomycete with substrate and aerial mycelia. The substrate mycelium exhibits various degrees of fragmentation. The aerial mycelium bears long straight chains of cylindrical spores with smooth surfaces, and sporangiumlike globular bodies 8 to 20 $\mu \mathrm{m}$ in diameter. The globules are surrounded by a membranous envelope and contain irregularly coiled hyphae but no spores. Motile spores are not formed by the strain.

The color of the aerial mycelium is white or yellow. The substrate mycelium penetrates the agar and is yellow, orange-yellow, or light brown depending on the medium. Melanoid pigments are formed. Acid is formed from various carbon compounds (Table 2). Potato starch is hydrolyzed. Grows at temperatures between 17 and $45^{\circ} \mathrm{C}$; the optimal temperature is $37^{\circ} \mathrm{C}$. Tolerates up to $4 \% \mathrm{NaCl}$.

Antagonistic properties: weakly active on Bacillus subtilis but inactive on Micrococcus luteus and fungal strains. Produces the antiviral agents cycloviracins $(16,17)$. Habitat: soil.

The type strain is strain R761-7 (= ATCC 55061). Monotypic.

\section{ACKNOWLEDGMENTS}

We are grateful to T. Oki for his encouragement throughout this work and to T. Tsuno and Y. Narita for the analysis of menaquinones and fatty acids.

\section{REFERENCES}

1. Akimov, V. N., L. I. Evtushenko, and S. V. Dobritsa. 1989. Pseudoamycolata halophobica gen. nov., sp. nov. Int. J. Syst. Bacteriol. 39:457-461.

2. Becker, B., M. P. Lechevalier, and H. A. Lechevalier. 1965. Chemical composition of cell-wall preparations from strains of various form-genera of aerobic actinomycetes. Appl. Microbiol. 13:236-243.

3. Bowen, T., E. Stackebrandt, M. Dorsch, and T. M. Embley.
1989. The phylogeny of Amycolata autotrophica, Kibdelosporangium aridum and Saccharothrix australiensis. J. Gen. Microbiol. 135:2529-2536.

4. Collins, M. D., T. Pirouz, M. Goodfellow, and D. E Minnikin. 1977. Distribution of menaquinones in actinomycetes and corynebacteria. J. Gen. Microbiol. 100:221-230.

5. Embley, M. T., J. Smida, and E. Stackebrandt. 1988. The phylogeny of mycolateless wall chemotype IV actinomycetes and description of Pseudonocardiaceae fam. nov. Syst. Appl. Microbiol. 11:44-52.

6. Goodfellow, M. 1989. Suprageneric classification of actinomycetes, p. 2333-2339. In S. T. Williams, M. E. Sharpe, and J. G. Holt (ed.), Bergey's manual of systematic bacteriology, vol. 4. The Williams \& Wilkins Co., Baltimore.

7. Lechevalier, H. A. 1989. Nocardioform actinomycetes, p. 23482404. In S. T. Williams, M. E. Sharpe, and J. G. Holt (ed.), Bergey's manual of systematic bacteriology, vol. 4. The Williams \& Wilkins Co., Baltimore.

8. Lechevalier, M. P. 1968. Identification of aerobic actinomycetes of clinical importance. J. Lab. Clin. Med. 71:934-944.

9. Lechevalier, M. P., C. D. Bievre, and H. Lechevalier. 1977. Chemotaxonomy of aerobic actinomycetes: phospholipid composition. Biochem. Syst. Ecol. 5:249-260.

10. Mertz, F. P., and R. C. Yao. 1988. Kibdelosporangium philippinense sp. nov. isolated from soil. Int. J. Syst. Bacteriol. 38:282-286.

11. Minnikin, D. E., L. Alshamaony, and M. Goodfellow. 1975. Differentiation of Mycobacterium, Nocardia, and related taxa by thin-layer chromatographic analysis of whole-organism methanolysates. J. Gen. Microbiol. 88:200-204.

12. Shearer, M. C., P. Actor, B. A. Bowie, S. F. Grappel, C. H. Nash, D. J. Newman, and Y. K. Oh, C. H. Pan, and L. J. Nisbet. 1985. Aridicins, novel glycopeptide antibiotics. I. Taxonomy, production and biological activity. J. Antibiot. 38:555-560.

13. Shearer, M. C., P. M. Colman, R. M. Ferrin, L. J. Nisbet, and C. H. Nash III. 1986. New genus of the Actinomycetales: Kibdelosporangium aridum gen. nov., sp. nov. Int. J. Syst. Bacteriol. 36:47-54.

14. Shearer, M. C., A. J. Giovenella, S. F. Grappel, R. D. Hedde, 
R. J. Mehta, Y. K. Oh, C. H. Pan, D. H. Pitkin, and L. J. Nisbet. 1986. Kibdelins, novel glycopeptide antibiotics. I. Discovery, production and biological evaluation. J. Antibiot. 39:1386-1394.

15. Shirling, E. B., and D. Gottlieb. 1966. Methods for characterization of Streptomyces species. Int. J. Syst. Bacteriol. 16:313340 .

16. Tsunakawa, M., N. Komiyama, O. Tenmyo, K. Tomita, K. Kawano, C. Kotake, M. Konishi, and T. Oki. 1992. New antiviral antibiotics, cycloviracins $B_{1}$ and $B_{2}$. I. Production, isolation, physico-chemical properties and biological activity. $\mathrm{J}$. Antibiot. 45:1467-1471.

17. Tsunakawa, M., C. Kotake, T. Yamasaki, T. Moriyama, M. Konishi, and T. Oki. 1992. New antiviral antibiotics, cycloviracins $B_{1}$ and $B_{2}$. II. Structure determination. J. Antibiot. 45:1472-1480.

18. Uchida, K., and K. Aida. 1979. Taxonomic significance of cellwall acyl type in Conynebacterium-Mycobacterium-Nocardia group by a glycolate test. J. Gen. Appl. Microbiol. 25:169-183. 